\title{
On the Relations between Vita Contemplativa and Vita Activa
}

\author{
Wojciech Załuski \\ Jagiellonian University, Cracow, Poland \\ wojciech.zaluski@uj.edu.pl \\ Received 19 September 2018; accepted 29 December 2018; published 30 April 2019.
}

\begin{abstract}
The goal of this paper is to formulate several observations on the psychological relations between vita contemplativa and vita activa (hereafter, respectively, VC and VA) which manifest in the context of the two following problems: (1) what basic psychological mechanisms may propel an agent to forsake one type of life for the sake of another; and (2) what effect an agent's deep involvement in VC may have for his attitude towards VA as well as for his manner of pursuing VA (if he decides to abandon VC and pursue this way of life). In the paper, the distinction is made between VC in the strong sense (metaphysically/religiously oriented) and $\mathrm{VC}$ in the weak sense, and it is argued, among others, that the two features of VC in the strong sense - selflessness and otherworldliness - make VC a desirable complement of VA (in its public form): the involvement in the public sphere motivated by VA is likely to be not only more effective, but also more durable than the involvement propelled by disappointment with the private VA. Therefore, human beings should not be thought of as (broadly) divided into two rarely interpermeating categories namely those who are 'psychologically destined' for VC and those who are 'psychologically destined' for VA. Rather, the opposite seems to be true, namely that there exist strong motivational links in the direction from VC to VA.
\end{abstract}

Keywords: vita activa; vita contemplativa; disappointment; selflessness; private life; public life.

\section{Vita contemplativa and vita activa: Introductory Distinctions}

This paper is devoted to the analysis of two types of psychological relations between vita contemplativa and vita activa (hereafter, respectively, VC and VA), viz. those which manifest in the context of the following two problems: (1) what basic psychological mechanisms may propel an agent to forsake one type of life for the sake of another; and (2) what 
effect an agent's deep involvement in VC may have for his attitude towards VA as well as for his manner of pursuing VA (if he decides to abandon VC and pursue this way of life). Since the paper is focused on the psychological relations between VC and VA, it does not aim at providing any insights into the problem of the axiological relations between these two ways of life, i.e. into the problem of which of them is 'better' or 'more valuable'. As will be shown, however, some conclusions regarding their mutual axiological relations can be derived from the psychological analyses.

Even though the concepts of VC and VA have rather clear intuitive meanings (VC being a way of life detached from the affairs of everyday existence, focused on the contemplation/pursuit of truth, while VA being a way of life engaged in worldly affairs, focused on realising various non-contemplative goals), some additional distinctions are indispensable. The first distinction concerns VC. This way of life may take two forms, which can be called 'strong' and 'weak', depending on the metaphysical assumptions accepted by those who decide to pursue it. The 'strong' form is anti- or supra-naturalistic: it assumes that nature is not all that exists and that what is not natural (and thereby is metaphysical) is the most proper object of contemplation. It does not imply that nature cannot be an object of contemplation, but it implies that whoever becomes seriously engaged in the contemplation of nature (or in the pursuit of truth regarding nature), is bound to reach, at some stage of his contemplative activity, a higher object (e.g. Platonic ideas or the God/Absolute/Logos). VC was understood in this way within the so-called classical (ancient and medieval) tradition of philosophy. Within this tradition, also some other elements of VC understood in this way were distinguished (cf. especially Pieper, 1998, pp. 73-110). They are worth mentioning as they will flesh out the somewhat general picture of $\mathrm{VC}$ in the strong sense presented so far:

(1) The sole goal of $\mathrm{VC}$ is to become engaged in the process of attaining the truth and, more importantly, to contemplate the truth once it is attained; VC has no other, ulterior, motive; it is an approach to reality which is entirely disinterested, "altogether independent of all practical aims in active life" (Pieper, 1998, p. 74).

(2) VC is a kind of knowing which is preceded or inspired by love; as Thomas Aquinas put it in Scriptum super Sententiis (3 d. 35, I, 21), Ubi amor, ibi oculos ("Where love is, there is the eye"). Accordingly, it is the love of the reality (broadly understood as including its physical and metaphysical 'side') which underlies contemplation; without this emotional condition which guarantees an 'openness' towards the whole richness and complexity of reality, its cognition and contemplation is not possible. Even though amor is an (emotional) condition of contemplation, it does not appear sine ratio: amor itself requires a (cognitive) condition, which Pieper aptly describes as the conviction that the "reality at bottom is good"- that "in spite of all appearances underlying all things is peace, salvation, gloria, that nothing and no one is lost (Pieper, 1998, p. 84)". He adds that "such non-rational, intuitive certainties of the divine base of all that is can be vouchsafed to our gaze even when it is turned toward the most insignificant-looking things, if only it is a gaze inspired by love. That, in the precise sense, is contemplation" 
(Pieper, 1998, p. 85). Thus, amor of reality - the condition of contemplationcannot appear if one does not have a "non-rational", "intuitive" certainty that "reality at bottom is good"-if, in other words, one is not open to the metaphysical, religious dimension of reality. But apart from amor of reality and its metaphysical basis (condition), the adherents of the classical (strong) view of $\mathrm{VC}$ point to one more (this time practical or psychological) precondition of contemplation, viz. leisure (otium, schole), especially its internal element: "a proper mental and spiritual attitude", which is opposed to that of acedia, and consists in the attitude of "nonactivity", "inward calm", "harmony", "silence", "the lack of restlessness" (cf. Pieper, 2009, pp. 46-48); the external element of otium-viz. freedom from the fetters of everyday duties - is of lesser importance and does not constitute a necessary condition of contemplation (at least according to the Christian philosophers, for the view of the ancient thinkers was different; most of them also emphasised the external element of leisure; the classical tradition is therefore not homogenous in this point).

(3) From the above features of contemplation, the other two can be derived: contemplation is accompanied by amazement and constitutes the supreme happiness of a human being; as Thomas Aquinas wrote in Summa Contra Gentiles $(3,37)$, Ultimi hominis felicitas est in contemplatione veritatis.

(4) Since the last stage (the acme) of VC is the contemplation - seeing, perception, theoria (in ancient Greek) — of the truth, not its pursuit, it is not surprising that the classical philosophers (e.g. Thomas Aquinas) emphasised that the mental faculty involved in it is intellectus (intuitive faculty) rather than ratio (discursive faculty); as Pieper metaphorically put it, summarising Aquinas's view, "The simple insightful gaze of intellectus is related to the discursive movement of the ratio as the eternal to the temporal" (Pieper, 1998, p. 102). Accordingly, while ratio enables one to move to the object of contemplation, intellectus makes it possible to embrace it in one comprehensive view and 'rest' in it. The emphasis placed upon intellectus as a faculty of contemplation also explains why the condition of amor of reality, i.e. the certainty that "reality is at bottom good", has a "nonrational" character; it is "non-rational", because it is (like contemplation itself) reached by intellectus, not by ratio.

The strong form of VC described above must be distinguished from its weak form - naturalistic and, thereby, deprived of its metaphysical, religious dimension. The essential elements of the 'metaphysical' VC are absent here: VC is conceived of as a constant move towards the truth rather than as its contemplation (in the original sense of 'seeing'); the pursued truth concerns the natural world and, therefore, does not necessarily lead to "amazement" (it cannot embrace metaphysical claims, such as that "reality is at bottom good" or that "the reality has divine base"). What is common for both forms of VC is that they represent a disinterested attitude to reality, i.e. the attitude of a spectator rather than that of an actor - of someone who desires to understand the world in the first place rather than act within it. One could ask whether the similarities between these two forms of VC 
are strong enough to speak about $\mathrm{VC}$ in general and, consequently, analyse its relations to VA. In my view, the similarities are indeed strong enough for that purpose, although in my further analysis I shall not discount the importance of the differences between them.

As for VA, it has two basic varieties. The first one is private; it consists in being focused on the matters from the narrow circle of one's privacy, such as taking care of one's children, spending time with friends, earning one's living, producing and accumulating wealth. Typical of this way of life is the concentration on one's private (including that of one's kith and kin) happiness. Here I omit, as unnecessary for the analysis, further possible distinctions within this way of life, e.g. between 'labour' and 'work' as proposed by Hannah Arendt in her chef d'oeuvre The Human Condition. The second variety of VA is public (political) and it consists in stepping out of the narrow circle of one's private matters into the public sphere in order to act for the sake of the public interest/good/happiness.

In the remainder of this paper, I shall investigate two psychological problems mentioned at the beginning of this paper: that of the motivation to leave a given way of life and that of the effects of the involvement in VC for the subsequent pursuing of VA (in its public form). The analysis relies on the assumption that one cannot pursue all the ways of life simultaneously. At first sight, this assumption might seem implausible, since it is not difficult to imagine a person who shares his time more or less equally between contemplation, the involvement in public life, and the concern with the well-being of his own and his kith and kin. This objection can be easily refuted by pointing out two facts. First, a person leading such a multiform life undertakes a rather challenging task, because these different ways of life demand different types of mental attitude, and a really effective engagement in one of them can constitute a hindrance for an effective engagement in the other. Second, and more importantly, it seems that even a person who tries to pursue this multiform way of life (embracing VC and VA in its two varieties) and somehow succeeds in pursuing them effectively, creates (more or less consciously) some inner 'ranking' of them. As a result, even with regard to such person, one can reasonably speak about transitions between different ways of life (in this case a transition would mean a change in his 'ranking' of the ways of life). However, and I shall repeat this, owing to a radically different character of VC, private $\mathrm{VA}$, and public VA, it seems that, as a rule, one of them distinctly dominates also in an external sense (expended quantity of time, energy, etc.) in a life of a given person, so the transition from one way of life to another takes, in the case of most people, a quite tangible form (manifesting in the change of behaviour).

\section{Disappointment as a Motive of 'Shifting' between Various Ways of Life}

In his short but penetrating study, titled Shifting Involvements: Private Interest and Public Action, Albert Hirschman advanced an insightful hypothesis that the main motive for "shifting" between two forms of VA is disappointment, which, in his view, is an important but unappreciated motive of human behaviour. He put it even more strongly, asserting that disappointment is a "central element of human experience" (Hirschman, 2002, p. 11); 
since, as he claimed, "human nature is intrinsically unsatisfiable, insatiable (ibidem)", we tend to expect too much from the reality and, as a result, we experience disappointment, a painful dissonance between desire and fulfilment. In this context, he invoked Kant's suggestive words from a letter to the Russian historian Nikolay Karamzin: "Give a man everything he desires and yet at this very moment he will feel that this everything is not everything". Hirschman insightfully remarked that the converse feeling - that of a "pleasant surprise" (for which, symptomatically, there is no one word) - is much less frequent, since reality seldom exceeds our expectations. He applied this original psychological hypothesis to the analysis of VA, reaching the conclusion that disappointment is the main endogenous motive (i.e. one coming from the very nature of a respective variety of VA as confronted with the insatiability of human nature) of shifting between two types of VA and, thereby, between the private sphere and the public sphere (he obviously did not deny the existence and importance of exogenous motives); as he put it, "The turns from the private to the public life and back again are marked by wildly exaggerated expectations, by total infatuation and by sudden revulsions" (Hirschman, 2002, p. 102). In his view, the passage from the private to the public sphere is most likely to take place among people with high socio-economic status, because they have already achieved the private happiness (at least as they imagined it) and, because of the insatiability of human nature, became "disenchanted" with it (cf. Hirschman, 2002, p. 75). Needless to say, this kind of motivation may fail to lead to the actual transition, because one may encounter various 'external' difficulties (e.g. the collective action problems: it may make little sense to enter the public sphere alone and it may be difficult to coordinate the entrance with other people). The passage in the reverse direction - from the public sphere to the private sphere-is likely to take place, because, as Hirschman convincingly argued, it belongs to the nature of the public (political) sphere that it rarely offers an adequate (satisfactory) level of involvement; it results in either over-involvement or under-involvement; "the problem with political life is that it is either too absorbing or too tame" (Hirschman, 2002, p. 119). One may therefore say that the passage to a different sphere of VA (leading to an oscillation between them) is mainly (if one focuses on endogenous motives only) a result of disappointment: public life is "a relief from the boredom of the private life", and private life is "a refuge from the paroxysms and futility of public endeavor" (Hirschman, 2002, p. 129). One could object, however, that Hirschman's description of the motives for leaving a given type of VA (boredom in the case of private VA and enervation or the sentiment of futility in the case of public VA) are not necessary elements of these ways of life, but, rather, depend on the idiosyncrasies of individual psychology. One could imagine, so the objection goes, a person who could find full satisfaction in pursuing a given form of VA. Hirschman would disagree; in his view, all human beings are fundamentally insatiable, i.e. their expectations, more or less explicitly formulated, always tend to exceed what reality can offer them and, as a result, bring about disappointment (they may try to conceal it in front of other people and themselves, but it is bound to appear).

Two points regarding the scope of Hirschman's analysis are in order here. 
Firstly, Hirschman did not try to provide an axiological comparison of the two varieties of VA: in contrast, for instance, to Hannah Arendt, who proposed several arguments for the superiority of public VA over private VA, ${ }^{1}$ he did not try to 'rank' these two varieties of VA. One may conjecture that his psychological theory of the essential 'insatiability' of human nature - insatiability ineluctably leading to disappointment —implies that none of them is obviously higher than the other. However it may be, it is clear that the author's analysis of the "shifts" between these two varieties of VA is, above all, descriptive. It is worth mentioning here that this (descriptive) analysis is further supplemented in his other book, namely The Passions and the Interests: Political Arguments for Capitalism before Its Triumph, with insightful historical remarks on the relations between the private and the public spheres. For instance, he identified three main reasons as to why the passage from the public to the private sphere came to be treated as legitimate (which happened in the $17^{\text {th }}$ and $18^{\text {th }}$ century):

(1) the pursuit of one's private, material interests started to be viewed as beneficial to the material well-being of the society as a whole (this is the 'Invisible Hand'type argument - an economic justification of capitalism);

(2) the pursuit of private, material interests came to be regarded as providing counterbalance for dangerous passions typical of the "life of intensive involvement with public affairs", such as "ambition, envy, and the reckless pursuit of glory and power" (Hirschman, 1997, p. 7); consequently, a 'spirit of commerce', with its characteristic (in the view of many thinkers, e.g. Montesquieu or James Steuart) virtues of moderation, tranquility, and practical wisdom, was expected to diffuse into political life and make it more calm and balanced.

The argument (2) is one of two forms of political justification of capitalism; the other form (invoked e.g. by James Steuart) is based on the (plausible) claim that the despotic government is less likely to appear in the state in which the economy reached a high level of complexity, since any arbitrary (despotic) interference with it might lead to its destruction or at least to its serious disturbance (argument 3); the interference is even less likely to occur if, as was emphasised by Montesquieu, the right to the private ownership of property has become deeply entrenched in the society. ${ }^{2}$

Secondly, Hirschman did not attempt to apply his theory of 'shifting involvements' to the analysis of the relations between VA and VC. Therefore, the question arises: can this theory describe the transitions between VA and VC just as convincingly as it describes the

\footnotetext{
${ }^{1}$ The most important of which seems to be her-undoubtedly controversial — claim that the values which can be realised in the former one, e.g. solidarity, impartiality, equality, courage, respect, and the value of realising one's capacity for judgment, are higher than the values which can be realised in the latter one, e.g. intimacy, love, compassion, pity, goodness.

${ }^{2}$ The political arguments for capitalism were later criticised by, among others, Alexis de Tocqueville, who pointed out that the material well-being, with its concomitant phenomena (the focus on one's wealth and the fear of losing it) may breed indifference to political life and make the appearance of some form of despotism ('mild', 'paternalistic' despotism) more likely.
} 
transitions between the two varieties of VA? Arguably, Hirschman's theory can plausibly describe the passage from VA (in both its varieties) to VC (in either of its two forms). However, this theory seems much less plausible as an account of the passage in the reverse direction, especially from VC in the strong form to VA. I shall now proceed to analyse this problem (one that is crucial to this paper) at somewhat greater length.

Hirschman wrote that the "world" he tried to "understand in this essay (Shifting Involvements) is one in which men think they want one thing and then upon getting it, find out to their dismay that they don't want it really as much as they thought or don't want it at all and that something else, of which they were hardly aware, is what they really want" (Hirschman, 2002, p. 21). One could argue, however, that the "world" which Hirschman tried to understand is not the world of $\mathrm{VC}$, or at least not the world of $\mathrm{VC}$ in the strong form. The classical thinkers, who developed the concept of VC in the strong form, admitted that human nature is insatiable and unsatisfiable, but they believed that it is its conditional feature: human nature is insatiable and unsatisfiable only if it seeks its fulfilment in the sphere of VA (they emphasised that a human being is, in his essence, a spirit which refers to the whole of reality and, as a result, cannot be satisfied by any particular part of it). The predicament of a human being focused on the material reality was expressed poignantly by Augustine of Hippo in Confessions (Book I, Chap. 1) in a memorable phrase: Quia fecisti nos ad te et inquietum est cor nostrum, donec requiescat in te. But, as was believed by Augustine and other Christian thinkers, a human being can silence or appease this 'disquiet of heart' if he directs his gaze towards the God/Absolute/Logos/Transcendence. Accordingly, $\mathrm{VC}$ (in the strong form) is the kind of life which should not breed disappointment: once we have become involved in it, we should feel no negative motivation (i.e. based on dissatisfaction/disappointment) to abandon it for the sake of another kind of life. In other words, there should not exist any endogenous motivation for abandoning $\mathrm{VC}$ in the strong form and, thereby, for getting involved in VA (though there may be, of course, various exogenous reasons, e.g. the necessity to defend one's country against aggressors, to fight for social justice, or to support one's relatives financially; all this could induce contemplative people to pursue VA). The classical thinkers invoked two main arguments for their claim about the superiority of VC over VA: from self-sufficiency and from the essence of a human being. They were clearly expressed by Aristotle in Book 10 of Nicomachean Ethics. He claimed, first, that contemplation exhibits self-sufficiency (autarkeia) more than any other human activity. He gave three different interpretations to this thesis:

(1) in contrast to ethical virtues (such as, among others, courage or justice), it does not require other people (we can be just only towards other people, but we can contemplate the truth in solitude);

(2) contemplation is much less dependent on the possession of external goods than any other activity, including the practice of ethical virtues (e.g. in order to be generous or just - in the sense of both distributive or commutative justice - we must have material goods; by contrast, contemplation can be practiced even by relatively poor people); 
(3) the value of ethical virtues is rooted partly in the beneficial effects they lead to, whereas the value of contemplation lies entirely 'in itself'.

Second, since he assumed that the 'essence' of a human being (i.e. his most typical feature that distinguishes him from other beings) is reason, he could assert that a human being's fulfilment (and also pleasure) will be the greatest in this type of activity in which reason acts most purely, with the least possible admixture of corporeal passions; this type of activity is, of course, the contemplation of the truth.

One must admit, however, that even according to the classical thinkers disappointment cannot be entirely excluded from VC, since our 'earthly' contemplation is not perfect - it is, as Thomas Aquinas put it in Summa Theologiae (II. II, q. 182, a. 2), quaedam inchoatio futurae felicitatis, only a kind of foretaste of the Eternal Beatitude; it cannot yield true happiness, vera felicitas, because, in our earthly life, it is, to some extent, corrupted by the temporary/transitory character of the human (terrestrial) existence. As Thomas Aquinas expressed it in Summa Theologiae (I. II, q. 5, a. 3):

Naturaliter enim homo desiderat permanentiam eius boni quo habit. Bona autem praesentis vitae transitoria sunt, cum et ipsa vita transeat, quam naturaliter desideriamus et eam perpetuo permanere vellimus, quia naturaliter homo refugit mortem. Unde impossibile est quod in haec vita vera beatitudo sit.

Therefore, not only is contemplation difficult to reach (which by itself would not imply that it cannot bring vera felicitas), but it is also impossible to maintain for an arbitrary, indefinite length of time (a contemplative person, because he is also a 'corporeal' being, cannot avoid returning to 'non-contemplative' activities). It is precisely this combination of the difficulty and the transience/fleetingness of contemplative experiences that may give rise to disappointment. It is true that in the course of contemplation a human being has a unique experience of time: he feels as if he stepped out of it, but, I shall repeat, this experience is not durable (though, as was emphasised by the classical thinkers, especially by Aristotle in Book 10 of Nicomachean Ethics, this is the most durable/continuous of all the positive human experiences). But, interestingly, according to the classical thinkers, the very fact that we can have at all this kind of experience shows that our nature is not entirely mortal and that there is something divine to it. Thomas Aquinas wrote, for instance, that intellectus - a faculty of contemplation, as one may call it-is a faculty non propre humana, sed superhumana. A similar point about the quasi-divine - not fully natural for human beings - character of $V C$ was made by Aristotle in the famous passage from the Book 10, Ch. 7 of Nicomachean Ethics:

[...] the activity of reason, which is contemplative, seems both to be superior in serious worth and to aim at no end beyond itself, and to have its pleasure proper to itself (and this augments the activity), and the self-sufficiency, leisureliness, unweariedness (so far as this is possible for man), and all the other attributes ascribed to the supremely happy man are evidently those connected with this activity, it follows that this will be the complete happiness of man, if it be allowed a complete term of life (for none of the attributes of happiness is incomplete). But such a life would be too high for man; for it is not in so far as he is man that he will live 
so, but in so far as something divine is present in him [...] If reason is divine, then, in comparison with man, the life according to it is divine in comparison with human life. But we must not follow those who advise us, being men, to think of human things, and being mortal, of mortal things, but must, so far as we can, make ourselves immortal, and strain every nerve to live in accordance with the best thing in us; for even if it be small in bulk, much more does it in power and worth surpass everything.

The above fragment from Aristotle, as well as the Christian thinkers' belief that a perfect and, thereby, a really satisfactory VC can be pursued only in the afterlife, both imply that $\mathrm{VC}$ is not fully natural for human beings in their terrestrial life. But they also imply that contemplation is the least disappointing of all human experiences. Nonetheless, it may be disappointing, because, as was mentioned, it is both difficult and transitory. The less-thantotal perfection of our 'earthly' contemplation explains why human beings who are involved in VC may indeed come to feel disappointed by this way of life and, as a result, may subsequently become involved in VA. However, what requires emphasis is the fact this disappointment does not come from the nature of VC (in the strong form); it is the result of an imperfection of human beings, who can rarely live up to this way of life and, if they do live up to it (and, thereby can really taste the moments of true contemplation), they (or, perhaps, most of them) cannot rest in it for a longer time.

It should be added here that, according to Aristotle, the very fact that the capacity for contemplation is a divine element of human nature - 'divine', since, as Aristotle emphasised, this is the only kind of activity which gods can pursue - was his another argument for the superiority of contemplation over other activities (including the practising of ethical-as opposed to dianoetic/intellectual-virtues). An important difference between the Greek and the Judeo-Christian visions of God can be seen here: for Greeks, God was above all intellect, whereas in the Judeo-Christian tradition God's intellect is less emphasisedfor Jews God was primarily justice, while for Christians God was primarily love. Accordingly, Aristotle's argument 'from' the divine character of contemplation for the superiority of VC over VA becomes less convincing within the Judeo-Christian tradition, which assumes that God not only contemplates, but also (or above all) performs ethical acts.

To summarise, VC may indeed breed disappointment (which may, in turn, motivate a transition to VA), but it breeds disappointment not because of its nature; by its nature it does not 'deceive' ${ }^{3}$ us, i.e. it does not raise the expectations which it cannot fulfil. It breeds disappointment only because of the limitations of our nature, which, because of its weakness and rootedness in temporal existence, can rarely be fully and never continuously engaged in VC. It is to be emphasised that the above conclusions, in so far as they stress the fact that $\mathrm{VC}$ is the least disappointing of all human experiences, refer in the first place to $\mathrm{VC}$ in the strong form. They refer in a much lesser degree to VC in the weak form, which is deprived of the metaphysical dimension and, thereby, cannot provide such a strong sense

\footnotetext{
${ }^{3}$ The words 'deception' and 'disappointment' are etymologically related; in French, the word 'déception' continues to refer to both.
} 
of fulfilment as VC in a strong form can. In other words, Hirschman's psychological theory seems to describe the passage from VC in the weak form to VA much better than from $\mathrm{VC}$ in the strong form to VA. However, as was argued above, this theory can also be helpful in the description of the latter transition.

\section{The Positive Motivational Links between vita contemplativa and vita activa}

In this section I will argue that VC (especially in the strong form) makes an agent who pursues it especially sensitive to external (exogenous) factors which justify the involvement in the public/political life and, additionally, that the previous pursuance of $\mathrm{VC}$ makes his involvement in the public/political particularly effective.

I shall start my argumentation with the following (rather uncontroversial) claim: the most precious psychological ground for pursuing public VA is a disinterested/selfless concern with the public happiness/good/interest. Now, it can hardly be doubted that this kind of motivation is strengthened by the involvement in $\mathrm{VC}$, especially in its strong form (though, obviously, VC is not a necessary condition of having such a motivation): it was, in fact, part of definition of $\mathrm{VC}$ in its strong form that it is pursued in a self-forgetful manner, in the spirit of the love of reality. The second claim (one that is more controversial than the previous one) is that the agent who has developed selflessness through the involvement in $\mathrm{VC}$ and who, as a result, has what can be called an abundance of selflessness, will desire to 'channel' it by (selflessly) acting for the sake of other people. ${ }^{4}$ This action may take two forms: he may want contemplata aliis tradere, for instance by spreading the knowledge he has acquired through contemplation (this way of leaving the solitude of VC may still be regarded as part of VC), or he may want to act for the public good/happiness/interest in a more tangible manner, i.e. by engaging in the public/political life, thus pursuing an activity which cannot be regarded as part of VC. Accordingly, VC is much more likely to give rise to an altruistic, 'public' motivation rather than to indifference to public/political affairs, as might be surmised at first glance and as was thought by many Roman citizens who were critical of Christianity (cf. Wilken, 2003; Ruggiero, 2007), and, later, by Niccolò Machiavelli and some other Renaissance thinkers, e.g. Coluccio Salutati, Leonardo Bruni, or Speron Speroni (cf. Garin, 1969; Domański, 1997; Berlin, 2013). But even in the works of the Italian public-oriented thinkers the critique is directed less against $\mathrm{VC}$ itself than against such a (distorted) understanding of it which justifies the inhuman isolation from other people as well as the contempt of the world. This understanding was distorted, because, let me repeat, $\mathrm{VC}$ as understood within classical tradition was based on the love of the reality - and not only of the supernatural but also of the 'earthly' reality. According to the classical understanding of contemplation (i.e. VC in the strong form), contemplation accompanied by contemptus mundi, i.e. indifference to the welfare of other

\footnotetext{
${ }^{4}$ This claim was defended, for instance, by Henri Bergsons, who has argued (in his book Les Deux sources de la morale et de la religion) that it is a part of a definition of a true/perfect contemplation/mysticism that it will lead to an (altruistic) action. Thus, on this view, action is not a 'weakening' of contemplation but its final stage.
} 
people, is simply a contradictio in adiecto. The distinction between these two ways - the non-isolationist and the isolationist — of understanding contemplation and the recognition that the isolationist one (i.e., deprived of the component of the love of reality) is distorted, can be found, perhaps somewhat surprisingly, in Machiavelli (who has an undeserved reputation of being a stringent and one-sided critic of Christianity). In Discorsi sopra la prima deca di Tito Livi (Book II, II), he expressly wrote that Christianity leads to the contempt of worldly affairs and to the indifference towards the well-being of the country only if it is wrongly interpreted - in the spirit of 'ozio' (idleness, sloth); if it is properly understood, it does not undermine the civic engagement of citizens.

Furthermore, it seems plausible to maintain that a person involved in VC (especially VC in the strong form) will act particularly effectively - bravely and non-opportunisticallyin the public sphere. The argument for this claim might run as follows. A person who lives $\mathrm{VC}$ in the strong form should become less fearful of death (and, thereby, less dependent on other people), because he does not consider the earthly life as the only life he has and/or because he exhibits a special sensitivity and attachment to ethical values (whose realisation he regards as his principal goal, overriding other goals). A contemplative person is also likely to have an especially valuable form of self-respect, viz. self-respect which is, to a large extent, independent of the recognition and appreciation by other people. This combination of inner freedom and self-respect allows him to be more faithful to his own conscience and to act more uncompromisingly in the world - uncompromisingly, but not fanatically (the love of reality excludes fanaticism: it gives rise to respect and also a certain kind of tenderness and compassion towards other people). One can give many historical examples of this kind of connection between pursuing VC and courage in VA: from Socrates through the Stoic philosophers and Christians, who were especially brave in opposing vicious Roman emperors (their courage stood out particularly against the background of the cowardice of most Roman senators, entirely immersed in VA), to Mahatma Gandhi or Martin Luther King. This connection is worth emphasising, because it is rarely recognised. According to the stereotypical image, a person leading $\mathrm{VC}$ is incapable of making decisions; exhibits intellectual over-subtlety, leading to skepticism; jealously guards his independence; values his inner freedom above all; is somewhat egocentric, timid, and pusillanimous. It may not be accidental that this image became a stereotype: many intellectuals did exhibit these features and either failed as politicians/public activists or distanced themselves from public activities. ${ }^{5}$ However, it would be implausible to maintain that there is a deeper connection between pursuing $\mathrm{VC}$ in the strong form and possessing the above features which lead to an awkward performance in the public/political life (though there may indeed be such connection between pursuing VC in the weak form-being an 'intellectualist', but not a 'contemplative' person in the strong sense-and having these features). The opposite seems to be true, namely that there is a deeper connection between $\mathrm{VC}$ in the strong sense and independence and courage in the public/political life. This

\footnotetext{
${ }^{5}$ Like, for instance, Erasmus from Rotterdam, at least as presented in the excellent biography by Stefan Zweig, in which the author expressed his admiration for Erasmus' intellectual qualities, but reproved him for not having enough determination and courage to act more resolutely in the public life.
} 
connection, as mentioned, was not often acknowledged. However, it was noticed and described insightfully by at least two thinkers, i.e. Gilbert K. Chesterton and Clive Staples Lewis. The former one wrote (in a somewhat exaggerated manner) that:

Lenin only fell into a slight error [in repeating Marx's words that religion is the opium of the people-WZ]; he only got it the wrong way round. The truth is that irreligion is the opium of the people. Wherever the people do not believe in something beyond the world, they will worship the world. But, above all, they will worship the strongest thing in the world. And, by the very nature of the Bolshevist and many other modern systems, as well as by the practical working of almost any system, the State will be the strongest thing in the world. (Chesterton, 1932, p. 59)

The latter one, in turn, claimed that:

Hope is one of the theological virtues. This means that a continual looking forward to the eternal world is not (as some modern people think) a form of escapism or wishful thinking, but one of the things a Christian is meant to do. It does not mean that we are to leave the present world as it is. If you read history you will find that the Christians who did most for the present world were just those who thought most of the next The Apostles themselves, who set on foot the conversion of the Roman Empire, the great men who built up the Middle Ages, the English Evangelicals who abolished the Slave Trade, all left their mark on Earth, precisely because their minds were occupied with Heaven. It is since Christians have largely ceased to think of the other world that they have become so ineffective in this. Aim at Heaven and you will get earth "thrown in": aim at earth and you will get neither. It seems a strange rule, but something like it can be seen at work in other matters. Health is a great blessing, but the moment you make health one of your main, direct objects you start becoming a crank and imagining there is something wrong with you. You are only likely to get health provided you want other things more-food, games, work, fun, open air. In the same way, we shall never save civilisation as long as civilisation is our main object. We must learn to want something else even more. (Lewis, 2014, pp. 73-74)

The above considerations demonstrate that there is no necessary tension between VA (in its public form) and VC (especially in the strong form). What is more, VC seems to be a desirable complement of VA (in its public form), not only (as argued above) because VC provides a proper motive for the involvement in the public sphere and public action is likely to be more effective (pursued more courageously and uncompromisingly) if motivated by unselfish motives developed within $\mathrm{VC}$, but also because the involvement in the public sphere motivated in this way is likely to be more lasting than if it were propelled by disappointment with the pursuit of private, material interests.

\section{Conclusions}

Let me summarize. $\mathrm{VC}$ in the strong form is much less prone to disappointment than VA in both its varieties (though, given the imperfections of the human nature and the transitoriness of human experiences, it is not entirely immune to disappointment). This psychological fact might be treated as an argument for the claim that VC stands higher in the 
hierarchy of the ways of life than VA. Two features of VC in the strong sense- - selflessness and otherworldliness (understood broadly, i.e. not necessarily in the strictly religious sense, but rather as a sensitivity to, and the recognition of, the metaphysical dimension of reality) — make VC a desirable complement of VA (in its public form): the involvement in the public sphere motivated by VA is likely to be not only more effective but also more durable than the involvement propelled by disappointment with the private VA. Therefore, it is implausible to maintain that there are two rarely interpermeating categories of human beings: those who are 'psychologically destined' for VC and those who are 'psychologically destined' for VA. The opposite thesis seems to be true: there exist strong motivational links in the direction from VC to VA.

\section{References}

Arendt, H. (1998). The Human Condition. Chicago, IL: The University of Chicago Press.

Aristotle. (1947). Nicomachean Ethics. (W. D. Ross, Transl.). New York, NY: The Modern Library. Augustin of Hippo. (2002). Confessiones. Torino, IT: Einaudi.

Berlin, I. (2013). The Originality of Machiavelli. In I. Berlin, Against the Current: Essays in the History of Ideas (pp. 33-100). Princeton, NJ: Princeton University Press.

Chesterton, G. K. (1932). Christendom in Dublin. London, UK: Sheed\&Ward.

Domański, J. (1997). Herakles na rozstaju dróg: Kontemplacja i działanie w humanizmie i scholastyce XIV i XV wieku, Znak, 5(504), 37-52.

Garin, E. (1969). Filozofia Odrodzenia we Włoszech. (K. Żaboklicki, Transl.). Warszawa, Poland: PWN.

Hirschman, A. (1997). The Passions and the Interest: Political Arguments for Capitalism before Its Triumph. Princeton, NJ: Princeton University Press.

Hirschman, A. (2002). Shifting Involvements: Private Interest and Public Action. Princeton, NJ: Princeton University Press.

Lewis, C. S. (2014). Mere Christianity. Yekaterinburg, Russia: Samizdat.

Machiavelli, N. (2005). Discorsi sopra la prima deca di Tito Livio. Milano, Italy: Garzanti.

Pieper, J. (1998). Happiness and Contemplation. (R. Winston, C. Winston, Transl.). South Bend, IN: St. Augustine's Press.

Pieper, J. (2009). Leisure: The Basis of Culture. (A. Dru, Transl.). San Francisco, CA: Ignatius Press.

Ruggiero, F. (2007). Szaleństwo chrześcijan: Poganie wobec chrześcijaństwa w pierwszych pięciu wiekach. (E. Łukaszyk, Transl.). Kraków, Poland: Wydawnictwo WAM.

Thomas Aquinas. Scriptum super Sententiis: Retrieved from: http://www.corpusthomisticum.org.

Thomas Aquinas. Summa contra Gentiles. Retrieved from: http://www.corpusthomisticum.org. 
Thomas Aquinas. Summa Theologiae. Retrieved from: http://www.corpusthomisticum.org.

Wilken, R. L. (2003). The Christians as the Romans Saw Them. New Haven, CT: Yale University Press.

Zweig, S. (2015). Erasmo da Rotterdam. (L. Mazzucchetti, Transl.). Milano, Italy: Tascabili Bompiani. 